\title{
PERAN C-FOS SEBAGAI AGEN PROLIFERASI DAN PRO-APOPTOSIS SEBAGAI STRATEGI PENGEMBANGAN PENGOBATAN KANKER
}

\author{
Aisyah Elliyanti ${ }^{1}$
}

\begin{abstract}
Abstrak
Analisis profil molekuler telah memberikan pengertian lebih dalam berkenaan dengan kompleksitas penyakit kanker di tingkat molekuler serta membuka potensi pengunaannya untuk mempelajari jalur onkogenik, hubungan jalur keganasan dengan sensitivitas terhadap terapi yang memberikan potensi yang besar sebagai petunjuk pengunaan terapi target. C-Fos merupakan proto-onkogen, berikatan dengan Jun membentuk komplek faktor transkripsi activating protein 1 (AP-1). Sebagai anggota dari AP1, c-Fos memainkan peran merespon transduksi sinyal proliferasi dan diferensiasi sel yang menyebabkan pertumbuhan sel yang invasif. Sebaliknya laporan penelitian lainnya membuktikan bahwa c-Fos juga memiliki peran sebagai tumor supresor dengan keterlibatannya pada proses apoptosis. Mekanisme molekuler yang jelas tentang keterlibatan c-Fos baik sebagai tumor modulator proliferasi sel maupun supresor pertumbuhan tumor masih belum jelas. Penelitian lebih lanjut keterlibatan c-Fos di tingkat molekuler sangat penting untuk membuka jalan bagi target baru terapi kanker maupun sebagai marker prognostik penyakit kanker.
\end{abstract}

Kata Kunci: c-Fos, proliferasi, pro-apoptosis, terapi target.

\begin{abstract}
Molecular profile analysis provide a better understanding related complexity of cancer disease and it opens to be used for oncogenic study pathways, sensitivity related therapy and as a guidelines for targeted therapy. C-Fos as a proto-oncogene, it dimerizes with Jun to form the transcription factor activating protein 1 (AP-1). As a member of AP-1, c-Fos acts as important component in the response to proliferative signals and cell differentiation that lead to invasive cell growth. In contrast, other publications reported that c-Fos also has a role as tumour supressor which involved in apoptosis. Molecular mechanism of role of c-fos as modulator of cell proliferation or tumour supressor is still unclear. Advance research regarding c-Fos role is important to open the way for new targeted therapy and prognostic of diseases.
\end{abstract}

Key words: c-Fos, proliferation, pro-apoptosis, targeted therapy

Afiliasi Penulis: 1. Bagian Fisika Fakultas Kedokteran Universitas Andalas/Kedokteran Nuklir RSUP M.Djamil Padang, HP: 08126636987, E-mail korespodensi: aelliyanti@yahoo.com 


\section{PENDAHULUAN}

Kemajuan pesat penelitian dasar berbasis molekuler memberi dampak pada pengelolaan penyakit tak terkecuali penyakit kanker. Hasil analisis profil molekuler telah memberikan sumbangan yang sangat berharga pada pengertian kompleksitas penyakit di tingkat molekuler, seperti potensi pengunaan analisis ekspresi gen untuk mempelajari jalur onkogenik, hubungan jalur keganasan dengan sensitivitas terhadap terapi yang memberikan potensi yang besar sebagai petunjuk pengunaan terapi target.

C-Fos merupakan proto-onkogen, berperan sebagai aktivator transkripsi, berikatan dengan c-Jun menbentuk komplek AP-1. ${ }^{1,2,3,4}$ Sebagai bagian dari keluarga dari AP-1, c-Fos memainkan peran penting pada tranduksi sinyal proliferasi dan diferensiasi sel, dan merupakan gen yang penting dalam pengaturan karsinogenesis, menekan gen supresor tumor sehingga mengakibatkan pertumbuhan kanker yang invasif. C-Fos menyebabkan hilangnya polaritas dan transisi epitel mesenkim yang mengakibatkan pertumbuhan invasif dan metastasis dari sel epitel payudara. 2,4,5,6

Penelitian lainnya melaporkan hal yang berbeda dari yang dilaporkan sebelumnya tentang peran c-Fos, dimana disebutkan bahwa c-Fos memiliki peran sebagai tumour-suppressor menyebabkan apoptosis. Ekspresi c-Fos yang berlebihan menghambat siklus pembelahan sel, dan menekan pembentukan tumor yang poten. ${ }^{5}$ Hasil kemoterapi pada pasien dengan kanker ovarium dan kolorektal ternyata lebih baik pada pasien yang diketahui mengekspresikan kadar c-Fos yang lebih tinggi dan diperkirakan bahwa c-Fos berperan sebagai tumor supresor, yang secara klinis dapat bermanfaat pada kasus kemoresisten. ${ }^{5}$

Berdasarkan berbagai penelitian yang telah dilakukan, bahwa c-Fos memainkan peran penting pada respon sinyal intraseluler baik menekan pertumbuhan ataupun merangsang pembentukan tumor. Peran c-Fos ini dapat dijadikan sebagai pintu masuk pengembangan terapi target pada penyakit kanker terutama yang resisten dengan pengobatan konvensional selama ini.

\section{METODE}

Penulisan artikel ini berdasarkan studi kepustakaan yang berhubungan dengan peran C-Fos sebagai agen proliferasi dan proapoptosis.

\section{HASIL DAN PEMBAHASAN}

\section{Struktur dan Pengaturan Ekspresi c-Fos}

C-Fos merupakan proto-onkogen, berperan sebagai aktivator transkripsi dari immediate early gene sebagai respon terhadap sinyal proliferasi. ${ }^{1,2}$ C-Fos merupakan keluarga Fos yang terdiri dari cFos, FosB, Fra-1, Fra-2, terdapat pada kromosom 14q21q31 dan mengkode 62kDa protein. Protein c-Fos terdiri dari 380 asam amino dengan domain transaktivasi pada terminus-c. Tidak seperti Jun, Fos tidak dapat membentuk homodimer dan ikatan Jun-Fos lebih stabil dibandingkan dengan ikatan JunJun. 2,8,9,10,11 Heterodimer dengan c-Jun menjadi komplek AP-1. Pada bagian promoternya c-Fos terikat pada TPA responsive elements (TREs) dan cAMP respon elements (CREs) yang memainkan peranan penting dalam berbagai respon seluler. ${ }^{8,10}$ 
Ekspresi c-Fos diatur diberbagai tingkatan jalur sinyal intraseluler, sehingga cFos bermanfaat sebagai marker bagi faktor indentifikasi dan karakteristik yang mempengaruhi pertumbuhan kanker. C-Fos merupakan downstream dari jalur epidermal growth factor receptor (EGFR) (gambar 1). Selain sebagai marker proliferasi c-Fos juga digunakan sebagai marker untuk menilai aktivasi EGFR dan terapi dengan menggunakan anti-EGFR ${ }^{1}$. Pada penelitian secara in-vitro menggunakan cell line A431, CAL 27, dan HN11 didapatkan peningkatan kadar c-Fos setelah distimulasi dengan EGF secara bermakna dan penurunan ekspresi cFos pada ketiga cell lines tersebut secara invivo pada pemberian Gefitinib dan Erlotinib, hal ini membuktikan bahwa kadar c-Fos tampak sejalan dengan pertumbuhan tumor. Namun demikian, respon yang berbeda diberikan oleh cell line HuCCTI dan Hep2, dimana kadar c-Fos tidak meningkat secara bermakan setelah stimulasi dengan EGF, demikian pula pada pemberian Gefitinib dan Erlotinib tidak memperlihatkan efek antiproliferasi. $^{1,12}$

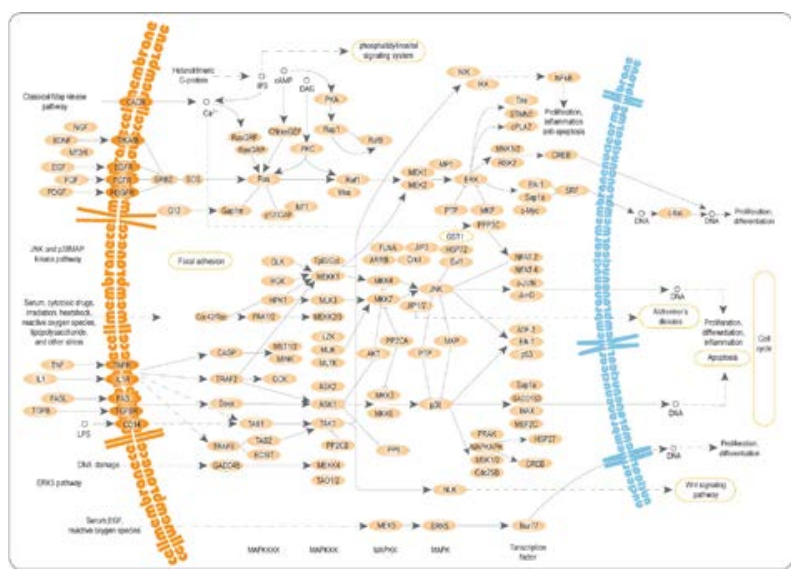

Gambar 1 : Jalur epidermal growth factor receptor (EGFR) (13)

Pada penelitian dengan menggunakan cell line keratinosit manusia yang di irriadiasi dengan menggunakan sinar ultra violet $A$, didapatkan ekspresi c-Fos meningkat melalui aktivitas p38 MAPK dan c-Jun N-terminal kinase (MAPK8). ${ }^{9}$ Stimulasi reseptor P2 melalui pemberian adenosine 5'-triphospate (ATP) juga dilaporkan bersinergi dengan faktor pertumbuhan mengaktifkan jalur ERK, phosphatidylminositol 3-kinase, protein kinase dan jalur Ca2+. ${ }^{12,14}$ Induksi sinyal sinyal intraseluler ini meningkatkan ekspresi c-Fos mRNA pada sel MCF712.

Reseptor P2 merupakan reseptor purinergik, yang distimulasi melalui pemberian ATP. Reseptor P2 terdiri dari dua subtipe yaitu $\mathrm{P} 2 \mathrm{Y}$ dan $\mathrm{P} 2 \mathrm{X} .{ }^{15}$ Reseptor $\mathrm{P} 2 \mathrm{X}$ memfasilitasi masuknya $\mathrm{Ca}+2$ dari ekstraseluler ke intraseluler, hal ini merupakan inisiator berbagai aktivitas sel. Pada osteoblas, sinyal dari reseptor $\mathrm{P} 2 \mathrm{X}$ mengaktifkan jalur ERK1/2 dan p38 MAPK dan menyebabkan c-Fos terekspresi. Aktivasi P38 MAPK memainkan peran penting dalam mengatur diferensiasi osteogenik pada human mesechymal steam cell (hMSC) dan menginduksi ekspresi c-Fos dan c-Jun. ${ }^{16}$

\section{Peran c-Fos}

Peningkatan ekspresi c-Fos dilaporkan seiring dengan peningkatan aktivasi faktor transkripsi AP-1. Peran AP-1 pada berbagai proses di tingkat seluler menyebabkan aktivasi gen target yang berbeda pada kondisi kondisi yang berbeda pula. ${ }^{5,6}$ Sebagai bagian dari AP-1, c-Fos merupakan modulator penting pada proses diferensiasi, proliferasi, transformasi dan apoptosis tergantung pada tipe sel dan lingkungannya. C-Fos berfungsi sebagai aktivator maupun supresor. ${ }^{4,5,10}$ Fungsi transisi dari kedua fungsi tersebut diatur melalui modifikasi post-translasi protein pada daerah terminalc, dengan kemungkinan terjadinya fosforilasi dari residu serin. Peran AP-1 pada berbagai proses di tingkat seluler memerlukan aktivasi 
gen target yang berbeda pada kondisi-kondisi yang berbeda pula. ${ }^{4,5}$

\section{Peran Pada Proses proliferasi}

Pada proses penyebaran sel tumor, terjadi kerusakan membran basal dan matrik ekstraseluler. Berbagai protein terlibat pada proses ini, sebagian besar sistim proteolitik diatur oleh faktor transkripsi AP- $1 .^{8}$ Sebagai bagian dari AP-1, c-Fos berperan pada tranduksi sinyal proliferasi dan diferensiasi sel menyebabkan pertumbuhan tumor yang invasif dan metastasis. Ekspresi c-Fos berkaitan erat dengan dengan ekspresi matrix metalo protein 9 (MMP9) yang mempengaruhi degradasi membran basal, dan merupakan pengatur yang penting pada kasus kanker payudara invasif. ${ }^{3,9}$ Penelitian lainnya menyebutkan bahwa c-Fos dapat menginduksi hilangnya polaritas dan transisi epitel mesenkim sehingga mengakibatkan pertumbuhan sel epitel payudara yang invasif, dan juga dilaporkan bahwa c-Fos merupakan prediktor independen menurunnya angka harapan hidup pada kasus kanker payudara. ${ }^{5}$

Pada kanker payudara, peningkatan kadar c-Fos dikaitkan dengan prognosis yang jelek dan supresi kadar c-Fos meningkatkan angka harapan hidup dan menghambat proses proliferasi dan invasi. ${ }^{4}$ Inhibisi c-Fos akan menekan proses proliferasi menyebabkan penurunan ekspresi AP-1.

\section{Peran Pada Apoptosis}

Pada laporan penelitian lainnya disebutkan pula bahwa c-Fos memiliki peran sebagai penekan pertumbuhan tumor melalui apoptosis. ${ }^{4,5,9,10}$ Penelitian secara in-vitro membuktikan bahwa c-Fos menekan faktor pertumbuhan independen yang distimulasi oleh onkogen $\mathrm{H}$-ras dan pada penelitian invivo terdapat bukti yang kuat bahwa c-Fos menekan pertumbuhan tumor. ${ }^{9}$ Observasi yang dilakukan pada karsinoma hepatoseluler mengindikasikan bahwa c-Fos merupakan mediator c-myc menginduksi kematian sel dan kemungkinan juga menginduksi apoptosis melalui jalur P38 mitogen-activated protein kinase (MAPK). Pada cell line leukemia sel T, Ligan Fas (FASL atau FasL) dan tumour necrosis factor-related apoptosis mengaktivasi ligan (TNFSF10 atau TRAIL) merupakan jalur apoptosis yang di induksi oleh c-Fos. Kemungkinan mekanisme lainnya keterlibatan c-Fos pada proses supresi pertumbuhan tumor dapat melalui pengaturan langsung BRCA1 yang merupakan faktor yang menentukan pada kanker payudara dan ovarium..$^{5,9,17}$ Pada penelitian lain yang menggunakan hepatosit mencit, induksi c-Fos mengakibatkan perubahan morfologi sehingga menyebabkan depolarisasi, menghambat proliferasi dan menyebabkan apoptosis dan menekan pembentukan tumor. ${ }^{5,9}$

Helicobacter pylori memiliki peran pada proses keganasan di lambung. Infeksi $H$. pylori meningkatkan ekspresi c-Fos yang menyebabkan aktivasi jalur MAPK. Peningkatan ekspresi protein c-Fos ini walaupun dapat merangsang proses karsinogenesis namun dapat pula merupakan mekanisme proteksi oleh sel lambung untuk menginduksi apoptosis sebelum infeksi mengarah pada proses keganasan. Aktivitas cFos sebagai tumor supresor dihubungkan dengan fungsi pro-apoptosis pada mukosa lambung. ${ }^{9}$

Apoptosis yang diinduksi melalui pemberian obat obatan, agen kimia, dapat disertai dengan peningkatan ekspresi c-Fos. Pada sebuah penelitian secara invivo disebutkan peran pro-apoptosis c-Fos terjadi 
selama masa pertumbuhan, remodeling dan respon terhadap stress dan laporan lainnya menyebutkan bahwa pemberian fenretinide atau $\mathrm{N}$-(4-hydroxyphenyl) retinamide (HRP) merupakan derivat dari asam retinoid menyebabkan peningkatkan ekspresi c-Fos dan bersama-sama menginduksi apoptosis pada cell line kanker ovarium A2780. Sebaliknya ekspresi c-Fos tidak tampak meningkat pada keadaan sel resisten dengan HPR. Pada cell line ovarium yang berasal dari manusia (SKOV-3, OVCA-432, OAW-42 dan IGROV-1) yang mana pertumbuhannya hanya dapat dihambat dengan dosis tinggi HPR dibanding dengan dosis yang diberikan pada cell line A2780, memperlihatkan bahwa peningkatan c-Fos hanya terjadi pada pemberian dengan dosis tinggi HPR. Pemberian HRP pada sel kanker ovarium meningkatkan apoptosis seiring peningkatan c-Fos dengan melibatkan peran AP-16.

Pada pemberian induktor apoptosis lainnya seperti retinoid sintetik seperti CD437 (6-(-2-naphthalene corboxylic acid) terjadi peningkatan kadar c-Fos pada berbagai tipe sel tumor seperti melanoma, tumor kepala dan leher, dan kanker prostat ${ }^{6}$. Peran c-Fos sebagai tumor supresor melalui fungsi proapoptosis dihubungkan juga dengan meningkatnya kemoresisten tumor pada kondisi kadar protein c-Fos yang rendah. ${ }^{5}$ Walaupun banyak penelitian telah memperlihatkan kontribusi c-Fos pada apoptosis namun mekanisme keterlibatan cFos pada peristiwa apoptosis masih belum jelas.

\section{SIMPULAN}

Terdapat bukti-bukti yang kuat bahwa cFos berperan ganda, baik menekan pertumbuhan ataupun merangsang pembentukan tumor. Peran ganda ini dapat disebabkan oleh berbedanya komposisi protein sel tumor dan lingkungannya seperti pasangan dimerisasi ko-aktivator dan arsitektur promoter. $^{9}$ Peran c-Fos yang berbeda ini terjadi pada jenis dan tipe kanker yang berbeda. Penelitian lebih lanjut mengenai keterlibatan c-Fos di tingkat molekuler sangat penting bagi pembuka jalan untuk pengembangan strategi pengobatan seperti target baru terapi kanker maupun sebagai marker prognostik penyakit kanker.

3. Milde-Langosch $\mathrm{K}$, Roder $\mathrm{H}$, Andritzky $\mathrm{B}$, Aslan B, Hemminger $G$, Brinkmann A, dkk. The Role of Ap-1 Transcription Factors c-Fos, Fos B, Fra-1 and Fra-2 in Invasion Process of Mamary Carcinomas. Breast Cancer Research and Treatment. 2004; 86:139-152

2. Jurado, J. Fuentes-Almagro CA, Prieto-Alamo $M$, Pueyo C. Alternative Splicing of c-Fos PremRNA: Contribution of The Rates of Synthesis and Degradation to The Copy Number of Each Transcript Isoform and Detection of Truncated c-Fos Immunoreactive Species. BMC Molecular Biology. 2007; 8:83
4. Lu C, S Q, DuPre E, Kim H, Hilsenbeck $S$, Brown PH. c-Fos is Critical for MCF7 Breast Cancer Cell Growth. Oncogene. 2005; 24:6516-6524

5. Mahner S, Baasch C, Schwarz j, Hein S, Wolber L, Midle-langosch K. C-fos Expression is a Molecular Predictor of Progression and 
Survival in epitelial Ovarian Carcinoma.British Journal of Cancer. 2008; 99:1269-1275

6. Appierto V, Villani MG, Cavadin E, Lotan R, Vinson C, Formelli F. Involvement of C-Fos in Fenretinide-Induced Apoptosis in Human Ovarian Carcinoma Cells. Cell Death and Differentiation. 2004; 11-270-279

7. Dahlman-Wright $K$, Qiao $Y$, Jonsson $P$, Gustafsson A, Williams C, Zhao C. Interplay Between AP-1 and Estrogen Receptor $\alpha$ in Regulating Gene Expression and Proliferation Networks in Breast Cancer Cells. Carcinogenesis. 2012; 33:1684-1691

8. Milde-Langosh $\mathrm{K}$, Bamberger CM, Rieck $\mathrm{G}$, Grund D, Hemminger G, Muller V, Loning $T$. Expression and Prognostic Relevance of Activated Extracellular-Regulated Kinase (ERK1/2) in Breast Cancer. British J of Cancer. 2005; 92:2206-2215.

9. Jin SP, Kim JH, Kim MA, Yang H, Lee HE, Lee HS, Kim WH. Prognostic Significance of Loss of c-Fos Protein in Gastric Carcinoma.Pathology Oncology Research. 2007; 13:284-289.

10. Yuan Z, Gong S, Luo J, Zheng Z, Song B, Ma S, dkk. Opposing Roles for ATF2 and c-Fos in cJun-Mediated Neuronal Apoptosis. Molecular and Cellular Biology. 2009; 29:2431-2442

11. Kharman-Biz A, Gao H, Ghiasvand R, Zhao C, Zendehdel K, Dalman-Wright K. Expression of Activator Protein-1 (AP-1) Family Members in Breast Cancer. BMC Cancer. 2013; 13:441

12. Wagstaff SC, Bowler WB, Gallagher JA, Hipskind RA. Extracellular ATP Activites Multiple Signalling Pathways and Potentiates Growth Factor-Induced c-fos Gene Expression in MCF-7 Breast Cancer Cells.Carcinogenesis. 2000; 21:2175-2181

13. Kosigirim. 2007. MAPKpathway melalui http://en.wikipedia.org/wiki/File:MAPKpathw ay.jpg [02/12/2014]

14. Ouadid-Ahidouch $H$, Roudbaraki $M$, Delcourt $P$, Ahidouch A, Joury N, Prevarskaya N. Functional dan Molecular Identification of
Intermediate-Conductance $\mathrm{Ca} 2+$-activated $\mathrm{K}+$ Channels in Breast Cancer Cell: Association With Cell Cycle Progression. AJP-Cell Physiol. 2004; 287:c125-c134

15. White N, Burnstock. P2 Receptors and Cancer. Trends in Pharmacological Science. 2006; 27:211-217

16. Sun $D$, Junger WG, Yuan $C$, Zhang $W$, Bao $Y$, Qin D, et all. Shockwaves Induce Osteogenic Differentiation of Human Mesenchymal Steam Cells Through ATP Release and Activation of P2X7 Receptors. Stem Cells. 2013; 31:1170:1180

17. Graves ML, Zhou L, MacDonald G, Mueller CR, Roskelley CD. Regulation of the BRCA1 Promoter in Ovarium Surface Epitelial Cells and Ovarian Carcinoma Cells. FEBS Letters. 2007; 81:1825-1833

18. Holliday DL, Speirs V. Choosing The Right Cell Line for Breast Cancer Research.Breast Cancer Research. BioMed Central. 2011; $13: 215$

19. Pusztai L, Mazouni C, Anderson K, Wu Y, Symmans WF. Molecular Classification of Breast Cancer: Limitation and Potential. The Oncologist. 2006; 11:868-877

20. Bland $\mathrm{KI}$, Konstadoulakis MM, Vezeridis MP, Wanebo HJ. Oncogene Protein Co-Expression (Value of Ha-ras, c-myc, c-fos, and p53 as prognostic Discriminants for Breast Carcinoma). Annals of Surgery. 1995; 221:706-720

21. Guller M, Toualbi-Abed K, Legrand A, Michel L, Mauviel A, Bernuau D, dkk. C-Fos Overexpression Increase The Proliferation of Human Hepatocytes by Stabilizing Nuclear Cyclin D1. World J Gastroenterol. 2008; 7:6339-6346

22. Volm M, Koomagi R, Mattern J, Efferth $T$. Expression Profile og Genes in Non-Smal Cell Lung Carcinomas From Long-Term Surviving Patients. Clinical Cancer research. 2002; 8:1843-1848 